\begin{tabular}{|c|c|}
\hline Journal STAND: Sports and Development \\
unipa Sumalaya & http://jurnal.unipasby.ac.id/index.php/stand/about/submissions \\
\hline
\end{tabular}

\title{
ANALISIS TINGKAT KEBUGARAN JASMANI PEMAIN SEPAK BOLA SEKOLAH SEPAK BOLA TANJUNG JAYA DAN SEKOLAH SEPAK BOLA UDDHATA
}

\author{
Arya T Candra ${ }^{1)}$, Rico Alvido Kurniawan') \\ ${ }^{1,2}$ Fakultas Olahraga Dan Kesehatan, Universitas PGRI Banyuwangi \\ aryacandra0189@gmail.com
}

\begin{tabular}{l}
\hline Artikel Info \\
\hline Koresponden penulis: \\
Arya T Candra \\
Email. \\
aryacandra0189@gmail.com \\
$\square$ Diterima 22 April 2020 \\
$\square$ Direview 12 Mei \\
$\square$ Disetujui 12 Mei 2020 \\
$\square$ Dipublikasi 27 Mei 2020 \\
\\
Kata Kunci: \\
TKJI, SSB Tanjung Jaya, SSB \\
Uddhata. \\
\hline
\end{tabular}

Keywords:

TKJI, SSB Tanjung Jaya, SSB Uddhata.

\begin{abstract}
Abstrak
Penelitian ini bertujuan untuk mengetahui perbedaan tingkat kebugaran jasmani siswa sekolah sepak bola Tanjung Jaya dan Uddhata usia 10-12 tahun. Teknik penentuan sampel dengan menggunakan total sampling. Sampel pada penelitian ini yaitu pemain sepakbola ssb tanjung jaya dan ssb uddhata sebanyak dari ssb tanjung jaya 24 pemain dan ssb uddhata 23 pemain. Dalam penelitian inipeneliti menggunakan tes kebugaran jasmani Indonesia (TKJ) untuk umur 10-12 tahun. Butir tes terdiri atas 5 item yaitu: lari 40 meter, gantung angkat tubuh, baring duduk, loncat tegak dan lari $600 \mathrm{~m}$. Berdasarkan hasil tes kesegaran jasmani siswa usia 10-12 tahun di sekolah sepakbola tanjung jaya dan uddhata yang berbeda di dapatkan data bahwa klasifikasi kesegaran jasmani sekolah sepakbola tanjung jaya yaitu: terdapat kategori baik sekali 13 orang siswa $(54,2 \%)$, kategori baik 11 orang siswa $(45,8 \%)$, kategori sedang tidak ada, kategori kurang tidak ada, kategori kurang sekali tidak ada. Untuk sekolah sepakbola uddhata yaitu: terdapat kategori baik sekali tidak ada, kategori baik 1 orang siswa $(4,3 \%)$, kategori sedang 15 orang siswa(65,2\%), kategori kurang 6 orang siswa $(26,2 \%)$, kategori kurang sekali 1 orang siswa $(4,3 \%)$.
\end{abstract}

\section{Abstract}

This study aims to determine differences in physical fitness levels of Tanjung Jaya and Uddhata soccer school students aged 10-12 years. The technique of determining the sample using total sampling. The samples in this study were the football players of Tanjung Jaya and SSB uddhata as many as 24 of the Tanjung Taya Jaya and 23 of the Suddhata players. In this study researchers used the Indonesian physical fitness test (TKJI) for ages 10-12 years. The test items consisted of 5 items: 40 meters running, body lifting, lying down, upright jumping and $600 \mathrm{~m}$ running. Based on the results of physical fitness tests for students aged 10-12 years at Tanjung Taya Jaya and uddhata soccer schools different data obtained that the physical fitness classification of Tanjung Jaya Football Schools namely: there are excellent categories of 13 students (54.2\%), good categories 11 students $(45.8 \%)$, medium category does not exist, category does not exist, category does not exist very much. For uddhata soccer school, namely: there is a very good category, one category is good, 1 student $(4.3 \%)$, the medium category is 15 students $(65.2 \%)$, the category is less than 6 students $(26.2 \%)$, the category 1 student was less $(4.3 \%)$. 


\begin{tabular}{|c|c|}
\hline Journal STAND: Sports and Development \\
unipa Sumalama
\end{tabular} $\begin{gathered}\text { htt//jurnal.unipasby.ac.id/index.php/stand/about/submissions } \\
\text { jurnal.stand@unipasby.ac.id }\end{gathered}$

\section{A. PENDAHULUAN}

Sekolah sekolah Tanjung Jaya adalah salah satu klub sepak bola di jember tepatnya di kecamatan Wuluhan desa Tanjung Rejo. Tim junior Tanjung Jaya dikenal sebagai tim tangguh dan beberapa kali melahirkan pemain pemain muda berbakat. Sekolah sepak bola Tanjung Jaya berdiri pada tahun 2012 prestasi sekolah sepak bola ini hanya memenangkan turnamen U15 pada tahun 2014 dan pencapaian itu tidak terulang lagi ditahun berikutnya. Sementara itu sekolah sepak bolaUddhata adalah salah satu klub sepak bola di jember tepatnya di kecamatan Ambulu desa Tegal Sari. Sekolah sepak bola ini tergolong sekolah sepakbola yang baru saja berdiri sekitar 4 tahun yang lalu tepatnya tahun 2015 dan banyak memenangkan kejuaraan tingkat junior dan mengikuti turnamen nasional yaitu Danone cup. Alasan mendasar peneliti mengangkat topik ini adalah untuk mengetahui perbedaan tingkat kebugaran jasmani pada kedua klub tersebut yang berdampak pada perbedaan perolehan tingkatprestasinya. Dan seberapa pentingnya kebugaran jasmani bagi pemain sepak bola untuk keterampilan teknik, taktik, fisik, dan mental pemain.

\section{B. KAJIAN LITERATUR}

Olahraga merupakan alat ampuh untuk pembentukan fisik dan mental bangsa, dengan sering berolahraga maka aktivitas sehari-hari juga akan terasa ringan (Hidayat, 2015). Menurut Utami (2015) Olahraga adalah sebagai bagian dari alat pembentuk karakter bangsa yang harus diperjuangkan. Aditia (2015) juga berpendapat bahwa olahraga adalah sebagai salah satu aktivitas fisik maupun psikis seseorang yang berguna untuk menjaga dan meningkatkan kualitas kesehatan seseorang tersebut setelah melakukan olahraga. Dengan melakukan olahraga akan meningkatkan kualitas kondisi fisik dari segi kebugaran jasmaninya.

Kondisi fisik merupakan salah satu komponen yang berpengaruh terhadap prestasi sebuah tim sepakbola selain komponen lain yaitu: keterampilan teknik, taktik, dan mental pemain. Kondisi fisik dalam olahraga sepakbola meliputi: daya tahan (endurance), daya ledak otot tungkai (explosive power), kecepatan (speed), dan kelincahan (agility). Menurut Al Kindi (2016) kondisi fisik adalah landasan olahraga prestasi yang terdiri dari komponenkomponen yang utuh dan tidak dapat dipisahkan satu sama lainnya. Sedangkan menurut Lufisanto (2014) Kondisi fisik merupakan unsur yang penting dan menjadi dasar dalam mengembangkan teknik, taktik, maupun strategi dalam bermain sepakbola. Menurut Miwoho, dkk(2011) Kondisi fisik adalah salah satu kesatuan utuh dari komponen-komponen yang tidak dapat dipisahkan begitu saja, baik peningkatanya, pemeliharaanya.

Menurut Mufiyadi (2013) Kebugaran jasmani merupakan kebutuhan pokok dalam melakukan aktivitas untuk kehidupan seharihari. Iskandar (2015) juga mengemukakan kemampuan seseorang untuk melakukan aktivitas sehari-hari tanpa mengalami kelelahan yang berlebihan. Hal ini sesuai dengan yang 


\begin{tabular}{|c|c|}
\hline Journal STAND: Sports and Development \\
unipa Sumalama
\end{tabular} $\begin{gathered}\text { htt//jurnal.unipasby.ac.id/index.php/stand/about/submissions } \\
\text { jurnal.stand@unipasby.ac.id }\end{gathered}$

dipaparkan Ilma (2016) Kebugaran jasmani adalah kondisi jasmani yang bersangkut-paut dengan kemampuan dan kesanggupannya berfungsi dalam pekerjaan secara optimal dan efisien. Sehingga, ada beberapa orang yang dalam kehidupan sehari-harinya tidak pernah melewatkan olahraga sebagai kegiatan rutinnya.

Untuk mengetahui tingkat kondisi fisik pada atlet sepakbola dapat diketahui tingkat kebugarannya dengan menggunakan tes TKJI. Kondisi fisik sangat penting perannya karena dapat menunjang keterampilan teknik, taktik, dan mental para pemain sepak bola. Kondisi fisik yang baik akan membuat pemain sepakbola mampu menampilkan kemampuan teknik dan taktik yang dimilikinya (Wahyuno, 2014). Kondisi fisik harus dilatih secara teratur dan terprogram sehingga mengalami peningkatan yang lebih baik dan berdampak pada kemampuan sebuah tim sepakbola untuk meraih prestasi (Maliki, 2016). Menurut Ardianto (2016) Sekolah sepakbola merupakan salah satu wadah yang tepatuntuk pengembangan potensi olahragasepakbola. Kemampuan fisik yang baik tentunya akan membantu pemain dalam menguasai teknik dasar bermain sepakbola. Oleh karena itu, kemampuan fisik dan teknik dasar merupakan syarat mutlak dalam sepakbola dan harus dimiliki setiap pemain sepakbola (Ardiyansyah, 2017).

Zahir (2018) Pembinaan fisik dan teknik dasardalamsepak bola di usia kanak-kanak usia 10-12 tahun perlu adanya pembinaan yang tepat dan terukur, perencaan yang sistematis, kemudian dilaksanakan secara bertahap dan berkesinambungan yang dimulai dari pemasalan, dan dilanjutkan dengan pembibitan untuk mencapai prestasi puncak. Sedangkan Kurniawati (2016) mengatakan setiap rentang usia juga mempengaruhi karakteristik dan perbedaan pertumbuhan seseorang dalam menentukan sikap.

\section{METODE PENELITIAN}

Penelitian ini merupakan penelitian deskriptif komparatif dengan metode survei dan pengumpulan datanya menggunakan tes dan pengukuran. Penelitian ini bertujuan untuk mengetahui perbedaan tingkat kebugaran jasmani siswa sekolah sepak bola Tanjung Jaya dan Uddhata usia 10-12 tahun. Teknik penentuan sampel dengan menggunakan total sampling. Sampel pada penelitian ini yaitu pemain sepakbola ssb tanjung jaya dan ssb uddhata sebanyak dari ssb tanjung jaya 24 pemain dan ssb uddhata 23 pemain. Dalam penelitian inipeneliti menggunakan tes kebugaran jasmani Indonesia (TKJI)untukumur 10-12 tahun. Butir tes terdiri atas 5 item yaitu: lari 40 meter, gantung angkat tubuh, baring duduk, loncat tegak dan lari $600 \mathrm{~m}$.

Data yang diperoleh dari tiap-tiap item tes merupakan data kasar yang dicapai pemain. Selanjutnya hasil kasar dari tiap-tiap butir tersebut diubah menjadi nilai dengan cara mengkonsultasikan hasil data kasar dari tiap-tiap butir tes yang telah dicapai oleh siswa sekolah sepak bola dengan menggunakan tabel nilai TKJI usia 10-12 tahun (Depdiknas, 2010). 


\begin{tabular}{|c|c|}
\hline Journal STAND: Sports and Development \\
unipa Sumalama
\end{tabular} $\begin{gathered}\text { htt//jurnal.unipasby.ac.id/index.php/stand/about/submissions } \\
\text { jurnal.stand@unipasby.ac.id }\end{gathered}$

Selanjutnya menjumlahkan nilai-nilai dari kelima butir Tes Kebugaran Jasmani Indonesia dan mengkonsultasikan ke dalam tabel norma TKJI usia 10-12 tahun sehingga akan terlihat hasil dari kesegaran jasmani siswa.

\section{HASIL DAN PEMBAHASAN HASIL}

Perbedaan tingkat kebugaran jasmani siswa sekolah sepakbola tanjung jaya dan uddhata ini di ukur berdasarkan hasil tes kebugaran jasmani Indonesia untuk usia 10-12 tahun yang meliputi lari 40 meter, gantung siku tekuk, baring duduk, loncat tegak, dan lari 600 meter. Hasil tes selanjutnya akan dinilai berdasarkan tabel nilai dan norma TKJI. Berikut data hasil penelitian pada SSB Tanjung Jaya peneliti sajikan pada tabel dibawah ini :

Tabel 1. Distribusi Frekuensi Nilai Hasil Tes Kebugaran Jasmani Sekolah Sepakbola Tanjung Jaya

\begin{tabular}{|c|c|c|c|c|}
\hline No & Interval & Frekuensi & Presentase & Kategori \\
\hline 1 & $22-25$ & 13 & 54,2 & Baik Sekali (BS) \\
\hline 2 & $18-21$ & 11 & 45,8 & Baik (B) \\
\hline 3 & $14-17$ & - & - & Sedang (S) \\
\hline 4 & $10-13$ & - & - & Kurang (K) \\
\hline 5 & $5-9$ & - & - & Kurang Sekali (KS) \\
\hline & Jumlah & 24 & 100 & \\
\hline
\end{tabular}

Berdasarkan data hasil penelitian dalam bentuk tabel diatas terkait hasil tes dan pengukuran TKJI yang didalamnya terdapat 5 item tes diantaranya: lari 40 meter, gantung siku tekuk, baring duduk, vertical jump dan lari 600 meter, maka peneliti sajikan dalam bentuk tampilan grafik pada gambar dibawah ini:
SSB TANJUNG JAYA

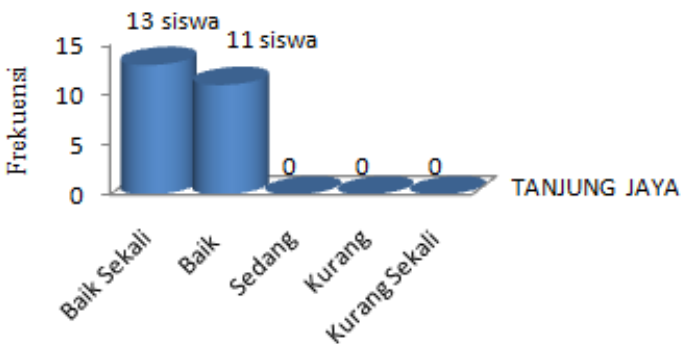

Kategori

Gambar 1. Grafik Grafik hasil tes kebugaran jasmani siswa sekolah sepakbola tanjung jaya

Berdasarkan grafik diatas, hasil tes kebugaran jasmani yang masuk kategori baik sekali 13 orang siswa $(54,2 \%)$, kategori baik 11 orang siswa (45,8\%), kategori sedang tidak ada, kategori kurang tidak ada, kategori kurang sekali tidak ada.

Berikut data hasil penelitian pada SSB Uddhata peneliti sajikan pada tabel dibawah ini:

Tabel 1. Distribusi Frekuensi Nilai Hasil Tes Kebugaran Jasmani Sekolah Sepakbola Uddhata

\begin{tabular}{|c|c|c|c|c|}
\hline No & Interval & Frekuensi & Presentase & Kategori \\
\hline 1 & $22-25$ & - & - & Baik Sekali (BS) \\
\hline 2 & $18-21$ & 1 & 4,3 & Baik (B) \\
\hline 3 & $14-17$ & 15 & 65,2 & Sedang (S) \\
\hline 4 & $10-13$ & 6 & 26,2 & Kurang (K) \\
\hline 5 & $5-9$ & 1 & 4,3 & Kurang Sekali (KS) \\
\hline \multicolumn{2}{|c|}{ Jumlah } & 23 & 100 & \\
\hline
\end{tabular}

Berdasarkan data hasil penelitian dalam bentuk tabel diatas terkait hasil tes dan pengukuran TKJI yang didalamnya terdapat 5 item tes diantaranya: lari 40 meter, gantung siku tekuk, baring duduk, vertical jump dan lari 600 meter, maka peneliti sajikan dalam bentuk tampilan grafik pada gambar dibawah ini: 


\begin{tabular}{|c|c|}
\hline & Journal STAND: Sports and Development \\
unipa Suralaya & http://jurnal.unipasby.ac.id/index.php/stand/about/submissions \\
\hline
\end{tabular}

\section{SSB UDDHATA}

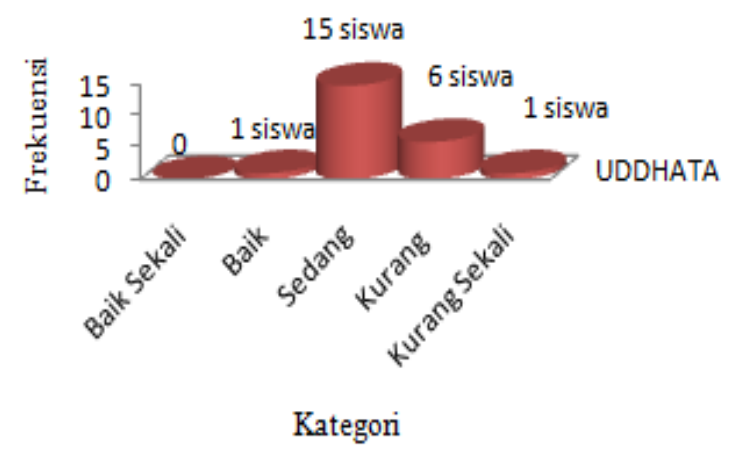

Gambar 2. Grafik hasil tes kebugaran jasmani siswa sekolah sepakbola uddhata

Berdasarkan grafik diatas, hasil tes yang masuk kategori baik sekali tidak ada, kategori baik 1 orang siswa $(4,3 \%)$, kategori sedang 15 orang siswa( $65,2 \%)$, kategori kurang 6 orang siswa $(26,2 \%)$, kategori kurang sekali 1 orang siswa $(4,3 \%)$.

Berikut adalah data perbandingan dari hasil tes TKJI SSB Tanjung Jaya dan SSB Uddhata peneliti sajikan pada grafik berikut:

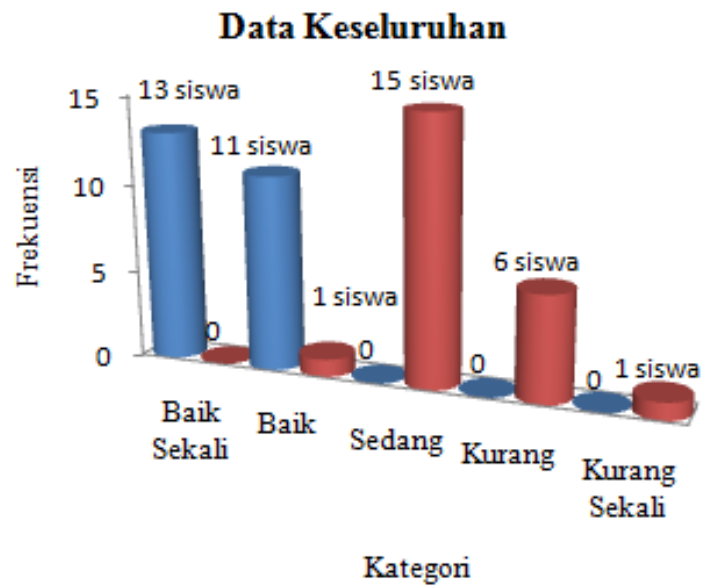

Gambar 3. Grafik Rekapitulasi Data Keseluruhan
Berdasarkan pembahasan hasil tes kesegaran jasmani pada siswa sekolah sepakbola tanjung jaya dan uddhatausia 10-12 tahun, selanjutnya peneliti membahas secara keseluruhan. Untuk data secara keseluruhan siswa sekolah sepakbola tanjung jaya, hasil tes yang masuk kategori baik sekali 13 orang siswa $(54,2 \%)$, kategori baik 11 orang siswa $(45,8 \%)$, kategori sedang tidak ada, kategori kurang tidak ada, kategori kurang sekali tidak ada. Untuk sekolah sepakbola uddhata, hasil tes yang masuk kategori baik sekali tidak ada, kategori baik 1 orang siswa $(4,3 \%)$, kategori sedang 15 orang siswa(65,2\%), kategori kurang 6 orang siswa $(26,2 \%)$, kategori kurang sekali 1 orang siswa $(4,3 \%)$.

\section{E. PEMBAHASAN}

Penelitian ini bertujuan untuk membandingkan tingkat kebugaran jasmani sekolah sepakbola tanjung jaya dan uddhata. Analisis dilakukan dengan menggunakan uji t. Dari hasil data penelitian di atas ternyata tingkat kesegaran jasmani siswa sekolah sepakbola tanjung jaya lebih unggul. Berdasarkan hasil analisis paired sample testkedua sekolah sepakbola telah diperoleh nilai sig. (2-tailed) $0,000>0,05$, hasil tersebut menunjukkan bahwa Ha: diterima Ho: ditolak dengan masuk kategori baik sekali 13 orang siswa $(54,2 \%)$, kategori baik 11 orang siswa $(45,8 \%)$, kategori sedang tidak ada, kategori kurang tidak ada, kategori kurang sekali tidak ada. Untuk sekolah sepakbola uddhata dengan masuk kategori baik 


\begin{tabular}{|c|c|}
\hline Journal STAND: Sports and Development \\
unipa Sumalama
\end{tabular} $\begin{gathered}\text { htt//jurnal.unipasby.ac.id/index.php/stand/about/submissions } \\
\text { jurnal.stand@unipasby.ac.id }\end{gathered}$

sekali tidak ada, kategori baik 1 orang siswa (4,3\%), kategori sedang 15 orang siswa(65,2\%), kategori kurang 6 orang siswa (26,2\%), kategori kurang sekali 1 orang siswa (4,3\%).

Dari hasil penelitian diatas bisa di deskripsikan per item tes yang mempunyai keunggulan yang berbeda-beda menurut item tesnya, untuk sekolah sepakbola tanjung jaya unggul dari kelima butir tes kesegaaran jasmani dikarenakan jarak tempat tinggal dekat dengan fasilitas (lapangan) jadi si siswa sekolah sepakbola tanjung jaya berpotensi sering melakukan aktifitas fisik atau latihan di lapangan.

Untuk sekolah sepakbola uddhata mendapat nilai lebih rendah dari kelima butir tes kesegaran jasmani disebabkan dari faktor jarak tempat tinggal dengan fasilitas (lapangan), latihan, aktifitas fisik, gaya hidup, dan latihan yang mempengaruhi kebugaran jasmani siswa sepakbola uddhata. Hal ini di sebabkan dari siswa itu sendiri dikarenakan mereka lebih senang memainkan gameonline daripada melakukan latihan. Pembahasan data diatas berdasarkan dari hasil wawancara dengan kedua pelatih. Hasil wawancara oleh peneliti dengan pelatih sekolah sepakbola tanjung jaya bahwa para siswa sekolah sepakbola tanjung jaya seringkali melakukan kegiatan fisik jogging di lereng gunung tanpa di intruksi dari pelatihnya. Hal tersebut tentunya juga berpengaruh terhadap tingkat kesegaran jasmani pada siswa tersebut. Hasil wawancara oleh peneliti dengan pelatih sekolah sepakbola uddhata bahwa para siswa sekolah sepakbola udhhata lebih senang memainkan gameonline yang lebih seru daripada latihan.Kondisi fisik yang baik akan membuat pemain sepakbola mampu menampilkan kemampuan teknik dan taktik yang dimilikinya (Wahyuno, 2014).Hal tersebut tentunya juga berpengaruh terhadap tingkat kesegaran jasmani pada siswa tersebut. Hal tersebut diperkuat oleh pernyataan (Maliki, 2016). Kondisi fisik harus dilatih secara teratur dan terprogram sehingga mengalami peningkatan yang lebih baik dan berdampak pada kemampuan sebuah tim sepakbola untuk meraih prestasi.Sedangkan menurut Lufisanto (2014) Kondisi fisik merupakan unsur yang penting dan menjadi dasar dalam mengembangkan teknik, taktik, maupun strategi dalam bermain sepakbola.

Ketika dikaji lebih dalam lagi terkait hasil perbandingan tingkat kesegaran jasmani (kondisi fisik) pada para siswa sekolah sepakbola, aktifitas fisik juga berpengaruh pada tingkat kondisi fisik mereka.

\section{F. SIMPULAN}

Berdasarkan hasil tes kesegaran jasmani siswa usia 10-12 tahun di sekolah sepakbola tanjung jaya dan uddhata yang berbeda di dapatkan data bahwa klasifikasi kesegaran jasmani sekolah sepakbola tanjung jaya yaitu: terdapat kategori baik sekali 13 orang siswa (54,2\%), kategori baik 11 orang siswa $(45,8 \%)$, kategori sedang tidak ada, kategori kurang tidak ada, kategori kurang sekali tidak ada. Untuk sekolah sepakbola uddhata yaitu: terdapat 


\begin{tabular}{|c|c|}
\hline Journal STAND: Sports and Development \\
unipa Sumalama
\end{tabular} $\begin{gathered}\text { htt//jurnal.unipasby.ac.id/index.php/stand/about/submissions } \\
\text { jurnal.stand@unipasby.ac.id }\end{gathered}$

kategori baik sekali tidak ada, kategori baik 1 orang siswa $(4,3 \%)$, kategori sedang 15 orang siswa $(65,2 \%)$, kategori kurang 6 orang siswa (26,2\%), kategori kurang sekali 1 orang siswa $(4,3 \%)$.

Dari data hasil tes diatas untuk sekolah sepakbola tanjung jaya lebih baik dibandingkan sekolah sepakbola uddhata. Maka dapat disimpulkan bahwasanya ada perbandingandan faktor yang mempengaruhi tingkat kesegaran jasmani pada siswa sekolah sepakbola tanjung jaya dan uddhata yaitu aktifitas kesehariannya yang aktif atau aktifitas fisik yang otomatis lebih baik dari yang kurang aktif.

\section{DAFTAR PUSTAKA}

Afandi, M, dkk (2013). Model dan metode pembelajaran di sekolah. Semarang : Unissula press.

Aditia, DA. (2015). Survey penerapan nilai-nilai positif olahraga dalam interaksi sosial antar siswa di sma negeri se-kabupaten wonosobo tahun 2014/2015

Al Kindi, JI. (2015). Futsal Putra Kelas Khusus Olahraga di SMAN 2 Ngaglik dan SMA N 1 Seyegan Kabupaten Sleman DIY

Ardiansyah, I. (2017). Tingkat kemampuan fisik dan teknik dasar pada siswa sekolah sepakbola baturetno usia 13-14 tahun di Bantul Yogyakarta

Ardianto, AW. (2016). Persepsi pelatih sekolah sepakbola (SSB) di Daerah Istimewa Yogyakarta pada pendidikan kepelatihan fakultas ilmu keolahragaan universitas negeri yogyakarta.

Hidayat, A. (2015). Survey perkembengan olahraga rekreasi gateball di Kab. Semarang Journal of Sport Sciences and Fitnes 4 (4) (2015)

Ilma, B. (2016).tingkat kesegaran jasmani peserta ekstrakurikulersepakbola di $\mathrm{mts}$ hasyim asy'ari piyungantahun ajaran 2016/2017 . skripsi. prodi pendidikan jasmani kesehatan dan rekreasijurusan pendidikan olahragafakultas ilmu keolahragaanuniversitas negeri Yogyakarta

Iskandar, SK. (2015). Perbedaan tingkat kebugaran jasmani pesertaekstrakurikuler sepakbola dan wushudi smp negeri 1 jogonalan.skripsi.Prodi Pendidikan Jasmani, Kesehatan dan Rekreasi Jurusan Pendidikan Olahraga Fakultas Ilmu Keolahragaan Universitas Negeri Yogyakarta

Kurniawati, D. (2016). Survey tingkat jasmani dan keterampilan gerak dasar sepakbola pada siswa SSB yunior putra usia 10-12 tahun kota kediri 2016

Lufisanto, MS. (2014). Analisis kondisi fisik yang memberi kontribusi terhadap tendangan jarak jauh pada pemain sepakbola.universitas negeri surabaya Fakultas ilmu keolahragaan Jurusan pendidikan kesehatan dan rekreasi Program studi s-1 ilmu keolahragaan

Mufiyadi, (2013) .Status Kebugaran Jasmani Sesuai Usia Kronologis dan Usia Mental 


\begin{tabular}{|c|c|}
\hline & Journal STAND: Sports and Development \\
unipa Suralaya & http://jurnal.unipasby.ac.id/index.php/stand/about/submissions \\
\hline
\end{tabular}

Serta Status Gizi peserta didik tunagrahita mampu didik di sekolah luar biasa c wiyata dharma 2 tempel, sleman.Program Studi Ilmu Keolahragaan Fakultas Ilmu Keolahragaan Universitas Negeri Yogyakarta

Soedjono,Zahir. L. (2018). Manajemen pembinaan sekolah sepakbola (SSB) Bina Bangsa Bandar Lampung. Fakultas keguruan dan ilmu pendidikan universitas lampung bandar lampung.

Utami, D. (2015). Peran Fisiologi Dalam Meningkatkan Prestasi OlahragaIndonesia Menuju Sea Games JurnalOlahraga Prestasi, Volume 11, Nomor 2, Juli 2015

Wiwoho, HA. Junaidi, S. Sugiharto. (2014).

Journal of Sport Sciences and Fitnes 